\title{
PENGUKURAN TINGKAT KEMANDIRIAN BELAJAR SISWA PADA PEMBELAJARAN JARAK JAUH MATA PELAJARAN DASAR PENANGANAN BAHAN HASIL PERTANIAN DI SMK PPN LEMBANG BERDASARKAN SIKAP SISWA KETIKA BELAJAR
}

\author{
Measuring of Student's Learning Independence Level in Distance Learning on Dasar \\ Penanganan Bahan Hasil Pertanian Subjects at SMK PPN Lembang Based on Student \\ Attitudes when Studying
}

\author{
Annisa Nuraeni Rahayu*, Siti Mujdalipah, Dwi Lestari Rahayu \\ Program Studi Pendidikan Teknologi Agroindustri, \\ Fakultas Pendidikan Teknologi dan Kejuruan Universitas Pendidikan Indonesia \\ *annisanuraenirahayu@upi.edu
}

\begin{abstract}
ABSTRAK
Peningkatan kasus Covid-19 di Indonesia menyebabkan kegiatan belajar mengajar dilaksanakan dari rumah melalui kegiatan Pembelajaran Jarak Jauh (PJJ) dengan memanfaatkan teknologi informasi dan komunikasi untuk mempermudah proses pembelajaran dan komunikasi antar guru dengan siswa. Ditemukan masalah pada kegiatan PJJ di SMK PPN Lembang dalam mata pelajaran DPBHP, yaitu perolehan hasil belajar siswa yang kurang optimal. Masalah tersebut memiliki keterkaitan dengan kemandirian belajar siswa, sebab ketika siswa ingin memperoleh hasil belajar yang baik maka siswa harus memiliki kemandirian belajar yang baik. Penelitian ini bertujuan untuk mengetahui tingkat kemandirian belajar siswa berdasarkan masing-masing indikator kemandirian belajar yang dilihat dari sudut pandang sikap siswa ketika belajar, yaitu aktif dalam belajar, tidak ketergantungan kepada orang lain, mampu mengontrol diri, percaya diri dalam belajar, disiplin dalam belajar, dan bertanggung jawab dalam belajar. Penelitian dilakukan dengan metode penelitian deskriptif dan teknik survei dengan menggunakan kuesioner. Hasil penelitian menunjukkan bahwa seluruh siswa memiliki tingkat kemandirian belajar dalam kategori tinggi hingga sangat tinggi pada indikator bertanggung jawab dalam belajar dan pada kelima indikator lainnya sebagian besar siswa memiliki tingkat kemandirian belajar dalam kategori tinggi hingga sangat tinggi. Diketahui juga dari hasil penelitian ini bahwa kemandirian belajar tidak menjadi penyebab utama perolehan hasil belajar siswa kurang optimal dalam kegiatan PJJ mata pelajaran DPBHP, sebab hasil belajar dipengaruhi juga oleh faktor eksternal siswa.
\end{abstract}

Kata kunci: indikator kemandirian belajar, pembelajaran jarak jauh, tingkat kemandirian belajar

\begin{abstract}
The increase of Covid-19 cases in Indonesia has caused teaching and learning activities to be carried out from home through distance learning activities by utilizing information and communication technology to facilitate the learning and communication process between teachers and students. There was a problem in distance learning activities at SMK PPN Lembang on DPBHP subjects, that is about student learning outcomes that were less than optimal. This problem is related to student learning independence because when students want to get good learning outcomes, students must have good learning independence. This study aims to determine student learning independence level based on each indicator of learning independence in the terms of students' attitudes when studying, that is being active in learning, not being dependent to others, being able to control themselves, confidence in learning, discipline in learning, and being responsible for learning. This research was using descriptive research methods and survey techniques by using questionnaires. The results showed that all students had a learning independence level in the high to the very high category on the indicators of being responsible for learning and another five indicators most of the students had a learning independence level in the high to very high category. It is also known from the results that learning independence is not the main cause of non-optimal student learning outcomes in distance learning activities on DPBHP subjects, because learning outcomes are also influenced by students' external factors.
\end{abstract}

Keywords: distance learning, indicators of learning independence, learning independence 


\section{PENDAHULUAN}

Wabah Covid-19 melanda dunia sejak Desember 2019, termasuk Indonesia yang mengonfirmasi kasus pertama pada bulan Maret 2020 dan terus mengalami peningkatan. Kebijakan dikeluarkan pemerintah Indonesia untuk memutus rantai penyebaran Covid-19 melalui instruksi bekerja, beribadah, dan belajar dari rumah. Kementerian Pendidikan dan Kebudayaan Republik Indonesia melalui Surat Edaran Mendikbud Nomor 04 Tahun 2020 tentang Pelaksanaan Kebijakan Pendidikan dalam Masa Darurat Penyebaran Coronavirus Disease (Covid-19) menginstruksikan untuk melaksanakan kegiatan belajar dari rumah dengan memberlakukan pembelajaran jarak jauh untuk seluruh jenjang pendidikan. Pembelajaran Jarak Jauh (PJJ) merupakan proses belajar mengajar yang tidak menempatkan guru dan siswa pada tempat yang sama, sehingga kegiatan pembelajaran dan komunikasi dilakukan dengan bantuan teknologi (Moore dan Kearsley, 2011). Di SMK PPN Lembang misalnya, kegiatan PJJ dilakukan dengan menggunakan aplikasi Google Classroom, Zoom, dan Whatsapp.

Di SMK PPN Lembang kegiatan PJJ berlaku untuk seluruh program studi, seluruh tingkatan kelas, dan seluruh mata pelajaran, termasuk program studi Agribisnis Pengolahan Hasil Pertanian (APHP) yang meskipun kegiatan pembelajaran dilakukan dari rumah, pihak program studi mengharapkan bahwa siswa tetap mampu memiliki kemampuan yang kompeten dalam bidang industri pengolahan sub sektor industri pangan dan minuman bidang teknologi hasil pertanian, seperti visi dan misi program studi (SMK PPN Lembang, 2021). Pada proses pencapaian tujuan tersebut, siswa APHP diharuskan mengusai mata pelajaran dasar program keahlian yang salah satunya adalah mata pelajaran Dasar Penanganan Bahan Hasil Pertanian (DPBHP), di mana mata pelajaran tersebut akan menunjang kompetensi siswa dalam mata pelajaran program keahlian lain. Hal itu dikarenakan, dalam mata pelajaran DPBHP siswa akan mempelajari mengenai karakteristik bahan hasil pertanian, perikanan, dan peternakan, termasuk cara penanganan dan pengolahan yang tepat agar kualitas bahan tersebut tidak rusak (Tim BSE, 2013).

Pelaksanaan pembelajaran dalam PJJ mata pelajaran DPBHP pada tahun ajaran 2020/2021 dilakukan dengan pemberian materi melalui media PowerPoint atau modul, pemberian tugas belajar, dan tugas praktikum mandiri, melalui kegiatan tersebut diharapkan dapat membantu pencapaian kompetensi siswa yang diinginkan. Namun ditemukan sejumlah masalah dalam pelaksanaannya, yaitu dari total 55 orang siswa, sebanyak $15-20$ orang siswa tidak menghadiri penjelasan materi secara langsung oleh guru yang dilakukan melalui aplikasi Zoom yang pelaksanaannya satu kali dalam satu bulan tanpa pemberitahuan, sebanyak 49\% siswa tidak mencapai nilai KKM (Kriteria Ketuntasan Minimal) dalam PTS (Penilaian Tengah Semester) pada semester ganjil tahun ajaran 2020/2021, dan dengan jumlah yang terus bertambah dari semula sebanyak dua orang siswa tidak mengerjakan tugas pada pemberian tugas belajar kedua hingga akhirnya menjadi 23 orang siswa tidak mengerjakan tugas pada pemberian tugas belajar keenam. Padahal melalui nilai ujian dan tugas belajar yang dikerjakan, guru dapat melakukan penilaian dan peninjauan untuk melihat keberhasilan kegiatan belajar dan pemahaman siswa terhadap materi pelajaran.

Masalah dalam pelaksanaan PJJ mata pelajaran DPBHP tersebut berkaitan erat dengan kemandirian belajar siswa. Hal itu dikarenakan, kemandirian belajar yang baik penting dimiliki oleh siswa untuk mencapai keberhasilan dalam pembelajaran dan dalam memperoleh nilai akademik yang optimal, terutama dalam pelaksanaan PJJ, sebab pembelajaran dilakukan dari rumah dan tidak adanya pengawasan dan pendampingan secara langsung dari guru, sehingga siswa harus lebih mengandalkan dirinya sendiri dalam kegiatan belajar agar dapat berhasil dalam kegiatan pembelajaran. Hasil belajar yang baik diperoleh tergantung dari usaha yang dilakukan siswa atas dasar kemandirian belajar siswa sendiri, sehingga untuk memperoleh hasil belajar yang baik dalam kegiatan PJJ diperlukan kemandirian belajar yang sangat tinggi, sebab terdapat korelasi positif antara kemandirian belajar siswa dengan hasil belajar siswa (Handayani dan Hidayat, 2018; Rohmat, 2014; Supianti, 2016).

Berdasarkan penjabaran di atas, maka penting untuk melakukan pengukuran tingkat kemandirian belajar siswa, sebab kemandirian belajar memiliki peran yang sangat penting dalam keberhasilan pembelajaran dan hasil belajar siswa, terutama dalam kegiatan PPJ. Melalui pengukuran tingkat kemandirian belajar ini, maka baik siswa, guru, dan orang tua akan mengetahui bagaimana tingkat kemandirian belajar yang dimiliki oleh siswa, di mana hal tersebut akan memudahkan siswa, 
guru, ataupun orang tua untuk mempertahankan atau meningkatkan kemandirian belajar siswa agar dapat meningkatkan keberhasilan pembelajaran dan hasil belajar siswa.

Pengukuran tingkat kemandirian belajar siswa dilakukan berdasarkan indikator kemandirian belajar, di mana seorang siswa dianggap memiliki kemandirian belajar yang baik ketika siswa telah mampu menerapkan indikator kemandirian belajar dalam kegiatan belajarnya. Pada penelitian ini indikator yang dijadikan sebagai acuan dalam pengukuran tingkat kemandirian belajar adalah indikator yang dilihat dari sudut pandang sikap siswa ketika belajar. Sikap siswa ketika belajar ini berpengaruh terhadap keberhasilan pembelajaran dan hasil belajar siswa. Hal tersebut dikarenakan terdapat hubungan positif yang signfikan antara sikap siswa dalam kegiatan belajar dengan hasil belajar siswa (Arif dan Samidjo, 2018). Indikator-indikator yang dilihat dari sudut pandang sikap siswa ketika belajar ini terdiri dari indikator aktif dalam belajar, indikator tidak ketergantungan kepada orang lain, indikator mampu mengontrol diri, indikator percaya diri dalam belajar, indikator disiplin dalam belajar, dan indikator bertanggung jawab dalam belajar (Febriastuti, 2013; Hidayati dan Listyani, 2010; Mudjiman, 2006).

Tujuan dari penelitian ini adalah untuk mengetahui tingkat kemandirian belajar siswa pada PJJ mata pelajaran DPBHP di SMK PPN Lembang pada tahun ajaran 2020/2021 berdasarkan masingmasing indikator kemandirian belajar yang dilihat dari sudut pandang siswa ketika belajar, agar dapat diketahui secara lebih spesifik mengenai tingkat kemandirian belajar siswa pada masing-masing indikator kemandirian belajar tersebut.

\section{METODE}

Metode penelitian yang digunakan dalam penelitian ini adalah metode penelitian deskriptif. Data penelitian dikumpulkan melalui teknik survei dengan menggunakan kuesioner dalam bentuk Google Form untuk selanjutnya di analisis secara deskriptif. Sampel yang digunakan dalam penelitian ini adalah seluruh siswa kelas X APHP di SMK PPN Lembang yang mengikuti kegiatan PJJ dalam mata pelajaran DPBHP pada tahun ajaran 2020/2021, yaitu sebanyak 55 orang siswa.

\section{Tahapan Penelitian}

\section{Penyusunan Instrumen Penelitian}

Instrumen penelitian yang digunakan berbentuk kuesioner dengan kisi-kisi instrumen penelitian yang didasarkan pada indikator kemandirian belajar yang dilihat dari sudut pandang sikap siswa ketika belajar, yaitu:

Tabel 1. Kisi-kisi Instrumen Penelitian

\begin{tabular}{ll}
\hline Indikator Kemandirian Belajar & Butir Pernyataan \\
\hline Aktif dalam belajar & 5 \\
\hline Tidak ketergantungan kepada orang lain & 8 \\
\hline Mampu mengontrol diri & 6 \\
\hline Percaya diri dalam belajar & 6 \\
\hline Disiplin dalam belajar & 5 \\
\hline Bertanggung jawab dalam belajar & 5 \\
\hline
\end{tabular}

\section{Validasi Instrumen Penelitian}

Validasi instrumen penelitian dilakukan terhadap kisi-kisi instrumen penelitian pada Tabel 1. dengan teknik Content Validity Index (CVI). Validasi dilakukan oleh validator yang berjumlah tiga orang, yaitu dua orang dosen pedagodik dan satu orang guru pengampu mata pelajaran DPBHP. Validasi dilakukan dengan mengukur kesesuaian antara setiap butir pernyataan dengan indikator kemandirian belajarnya. Pengukuran didasarkan pada skala pengukuran dalam CVI pada Tabel 2. Hasil skala pengukuran pada setiap butir pernyataan yang diberikan oleh validator akan dilakukan dikotomisasi skala pengukuran dengan aturan dikotomisasi seperti pada Tabel 3. 
Tabel 2. Skala Pengukuran dalam CVI

\begin{tabular}{|c|c|c|}
\hline Skala Pengukuran & \multicolumn{2}{|c|}{ Keterangan } \\
\hline 1 & \multicolumn{2}{|c|}{ Tidak Relevan } \\
\hline 2 & \multicolumn{2}{|c|}{ Agak Relevan } \\
\hline 3 & \multicolumn{2}{|c|}{ Cukup Relevan } \\
\hline 4 & \multicolumn{2}{|c|}{ Sangat Relevan } \\
\hline \multicolumn{3}{|c|}{$\begin{array}{c}\text { Sumber: Polit dan Beck (2006) } \\
\text { Tabel 3. Dikotomisasi Skala Pengukuran }\end{array}$} \\
\hline $\begin{array}{c}\text { Skala } \\
\text { Pengukuran }\end{array}$ & Dikotomisai & Keterangan \\
\hline 1 & 0 & Tidak Relevan \\
\hline 2 & 0 & Tidak Relevan \\
\hline 3 & 1 & Relevan \\
\hline 4 & 1 & Relevan \\
\hline
\end{tabular}

Sumber: Polit dan Beck (2006)

Skala pengukuran pada setiap butir pernyataan yang telah di dikotomisasi selanjutnya di uji validitas dengan menggunakan rumus I-CVI oleh Polit dan Beck (2006), di mana jumlah butir pernyataan yang bernilai relevan dari seluruh validator dibagi dengan jumlah total validator. Lynn (dalam Hendryadi, 2017) menjelaskan bahwa butir pernyataan dianggap valid ketika nilai I-CVI adalah $0,78-1,00$.

\section{Pengumpulan Data}

Instrumen penelitian yang telah valid diberikan kepada responden melalui Google Form, di mana nantinya responden memilih jawaban dari setiap butir pernyataan yang sesuai dengan penilaian dirinya. Pilihan jawaban disediakan dalam bentuk skala likert dengan rentang nilai 1-4.

Tabel 4. Kategori Jawaban Instrumen Penelitian

\begin{tabular}{|c|c|}
\hline Kategori Jawaban & Penilaian \\
\hline Sangat Sesuai & 4 \\
\hline Sesuai & 3 \\
\hline Tidak Sesuai & 2 \\
\hline Sangat Tidak Sesuai & 1 \\
\hline
\end{tabular}

\section{Pengolahan Data}

Data hasil penelitian yang diperoleh dari jawaban responden selanjutnya diolah untuk mengetahui tingkat kemandirian belajar siswa pada masing-masing indikator kemandirian belajar yang didasarkan pada sikap siswa ketika belajar dengan melakukan interpretasi data tersebut ke dalam kategori hasil penelitian. Pengkategorian tingkat kemandirian belajar siswa dimulai dengan melakukan perhitungan untuk mencari nilai $\bar{X}$ dan Sbx pada setiap indikator kemandirian belajar. Perhitungan nilai $\bar{X}$ dan Sbx dilakukan berdasarkan rumus Djemari (2008), yaitu:

$\bar{X} \quad=1 / 2$ (skor maksimal + skor minimal)

$\mathrm{SBx}=1 / 6$ (skor maksimal - skor minimal)

Keterangan:

$\overline{\mathrm{X}} \quad=$ data maksimal ideal pada satu indikator kemandirian belajar

$\mathrm{Sbx}=$ simpanan baku maksimal ideal pada satu indikator kemandirian belajar

Pengkategorian tingkat kemandirian belajar siswa dilanjutkan dengan melakukan perhitungan terhadap interval nilai dengan menggunakan nilai $\bar{X}$ dan Sbx yang telah diperoleh, termasuk juga dengan data responden dari seluruh butir pernyataan dalam satu indikator kemandirian belajar yang telah dijumlahkan. Setelah interval nilai diperoleh, maka data responden yang telah dijumlahkan dalam satu indikator diinterpretasi ke dalam kategori hasil penelitian. Interval nilai dan kategori hasil penelitian dapat dilihat pada Tabel 5. 
Tabel 5. Kategori Hasil Penelitian

\begin{tabular}{ll}
\hline Interval Nilai & Kategori \\
\hline $\mathrm{X} \geq \overline{\mathrm{X}}+1 . \mathrm{SBx}$ & Sangat tinggi \\
\hline$\overline{\mathrm{X}} \leq \mathrm{X}<\overline{\mathrm{X}}+1 . \mathrm{SBx}$ & Tinggi \\
\hline $\bar{X}-1 . \mathrm{SBx} \leq \mathrm{X}<\overline{\mathrm{X}}$ & Rendah \\
\hline $\mathrm{X}<\overline{\mathrm{X}}-1 . \mathrm{SBx}$ & Sangat rendah \\
\hline
\end{tabular}

Keterangan:

$X=$ jumlah data yang diperoleh responden pada satu indikator kemandirian belajar

\section{Persentase Kemandirian Belajar Siswa}

Data dalam bentuk persen ini merepresentasikan banyaknya siswa yang memiliki kemandirian belajar dalam satu kategori data hasil penelitian. Rumus persentase yang digunakan adalah sebagai berikut:

Keterangan:

$$
\%=\mathrm{X} / \mathrm{n} \times 100 \%
$$

$\mathrm{X}=$ banyaknya responden dalam suatu interval nilai kategori data

$\mathrm{n} \quad=$ total responden keseluruhan

\section{HASIL DAN PEMBAHASAN}

Kenampakan 3 formulasi cocogurt secara umum memiliki tekstur yang kental karena adanya penambahan pektin, berwarna putih keruh hasil dari homogenisasi seluruh bahan, rasa khas campuran pisang dengan susu atau santan kelapa yang asam seperti yoghurt pada umumnya, dan aroma khas campuran pisang dan susu atau santan kelapa.

\section{Uji Validitas}

Hasil uji validitas yang diperoleh dari validasi instrumen penelitian yang dilakukan dengan teknik CVI menunjukkan bahwa pada indikator aktif dalam belajar sebanyak empat butir pernyataan dinyatakan valid dan satu butir pernyataan dinyatakan tidak valid, pada indikator tidak ketergantungan kepada orang lain sebanyak lima butir pernyataan dinyatakan valid dan tiga butir pernyataan dinyatakan tidak valid, serta pada indikator mampu mengontrol diri dan indikator percaya diri dalam belajar masingmasing sebanyak lima butir pernyataan dinyatakan valid dan satu butir pernyataan dinyatakan tidak valid, sementara pada indikator disiplin dalam belajar dan indikator bertanggung jawab dalam belajar masing-masing sebanyak empat butir pernyataan dinyatakan valid dan satu butir pernyataan dinyatakan tidak valid. Total butir pernyataan yang dinyatakan valid dari keenam indikator kemandirian belajar berjumlah 27 butir pernyataan, di mana butir pernyataan tersebut digunakan dalam kuesioner penelitian berbentuk Google Form pada pengukuran tingkat kemandirian belajar siswa kelas X APHP di SMK PPN Lembang dalam PJJ mata pelajaran DPBHP pada tahun ajaran 2020/2021, sementara 8 butir pernyataan lainnya yang dinyatakan tidak valid tidak digunakan dalam kuesioner penelitian tersebut.

\section{Tingkat Kemandirian Belajar Siswa Berdasarkan Indikator Kemandirian Belajar dari Sudut Pandang Sikap Siswa ketika Belajar}

\section{a. Indikator Aktif dalam Belajar}

Hasil pengukuran tingkat kemandirian belajar siswa berdasarkan indikator aktif dalam belajar menunjukkan, bahwa sebagian besar siswa memiliki tingkat kemandirian belajar yang termasuk ke dalam kategori tinggi hingga sangat tinggi. Tetapi masih terdapat cukup banyak siswa yang memiliki tingkat kemandirian belajar pada kategori rendah hingga sangat rendah, yaitu masing-masing sebanyak 18,18\% siswa dan 10,91\% siswa. Hasil tersebut dapat dilihat pada Tabel 6 . 
Tabel 6. Tingkat Kemandirian Belajar Siswa Berdasarkan Indikator Aktif dalam Belajar

\begin{tabular}{cccc}
\hline Interval Nilai & $\begin{array}{c}\text { Kategori Tingkat } \\
\text { Kemandirian Belajar }\end{array}$ & $\begin{array}{c}\text { Jumlah } \\
\text { Siswa }\end{array}$ & $\begin{array}{c}\text { Persentase } \\
(\%)\end{array}$ \\
\hline$X \geq 12$ & Sangat Tinggi & 23 & 41,82 \\
\hline $10 \leq X<12$ & Tinggi & 16 & 29,09 \\
\hline $8 \leq X<10$ & Rendah & 10 & 18,18 \\
\hline$X<8$ & Sangat Rendah & 6 & 10,91 \\
\hline \multicolumn{2}{c}{ Jumlah } & 55 & 100 \\
\hline
\end{tabular}

Keterangan: $\mathrm{X}=$ total nilai siswa pada indikator ini

Secara lebih spesifik dalam pengukuran tingkat kemandirian belajar siswa pada indikator ini diketahui juga, bahwa terdapat aspek dalam indikator ini yang kurang diterapkan oleh siswa, yaitu aspek dalam hal selalu berpendapat ketika pembelajaran berlangsung, terbukti dari aspek tersebut yang memperoleh nilai terendah dalam pengukuran tingkat kemandirian belajar berdasarkan indikator ini. Nilai tersebut dapat dilihat pada Tabel 7.

Tabel 7. Penerapan Kemandirian Belajar oleh Siswa Berdasarkan Pernyataan pada Indikator Aktif dalam Belajar

\begin{tabular}{|c|c|c|c|c|c|c|}
\hline \multirow{2}{*}{$\begin{array}{l}\text { Nomor } \\
\text { Pernyataan }\end{array}$} & \multirow{2}{*}{ Pernyataan } & \multicolumn{4}{|c|}{ Jumlah Siswa } & \multirow{2}{*}{$\begin{array}{l}\text { Total } \\
\text { Skor }\end{array}$} \\
\hline & & 1 & 2 & 3 & 4 & \\
\hline P1 & $\begin{array}{l}\text { Saya selalu menanyakan kepada guru mata } \\
\text { pelajaranDPBHP apabila terdapatmateri pelajaran } \\
\text { yang belum dipahami }\end{array}$ & 2 & 24 & 24 & 5 & 142 \\
\hline P2 & $\begin{array}{l}\text { Saya menanyakan kepadateman apabila terdapat } \\
\text { materi DPBHP yang belum saya pahami. }\end{array}$ & 2 & 9 & 18 & 26 & 178 \\
\hline P3 & $\begin{array}{l}\text { Saya selalu menanyakan kepada guru mata } \\
\text { pelajaranDPBHP apabila terdapatinstruksi tugas } \\
\text { yang diberikan dalam kegiatan PJJ kurang saya } \\
\text { pahami. }\end{array}$ & 2 & 16 & 32 & 5 & 150 \\
\hline P4 & $\begin{array}{l}\text { Saya selalu menyampaikan pendapat saya dalam } \\
\text { pertemuan PJJ pada matapelajaran DPBHP yang } \\
\text { dilakukan melalui aplikasi Zoom. }\end{array}$ & 10 & 30 & 13 & 2 & 117 \\
\hline
\end{tabular}

Keterangan: 1 = Sangat Tidak Sesuai, 2 = Tidak Sesuai, 3 = Sesuai, 4 = Sangat Sesuai

Informasi yang diperoleh dari hasil pengukuran tingkat kemandirian belajar siswa pada indikator ini menunjukkan juga, bahwa aspek yang kurang diterapkan oleh siswa tersebut dapat menjadi salah satu penyebab dari kurang optimalnya hasil belajar siswa. Hal itu dikarenakan apabila siswa telah berani dan mampu untuk mengemukakan pendapatnya ketika pembelajaran berlangsung, maka siswa tersebut telah memahami materi yang dipelajari dengan baik dan hal itu akan berdampak baik terhadap hasil belajar siswa. Kemampuan siswa untuk berpendapat akan muncul apabila dalam kegiatan belajarnya siswa telah mengalami pengembangan pengetahuan, di mana dengan pengembangan pengetahuan itu akan meningkatkan hasil belajar siswa (Andriessen dan Baker, 2014; Mustajab, Sriyono, dan Fatmaryanti, 2012).

Berdasarkan hal tersebut, maka perlu upaya untuk meningkatkan kemampuan siswa dalam menerapkan aspek untuk selalu berpendapat dalam kegiatan belajarnya, yaitu dengan cara siswa perlu meningkatkan rasa percaya diri dan melawan rasa takut untuk berpendapat melalui peningkatan pemahaman terhadap materi pelajaran. Ketika kemampuan siswa dalam menerapkan aspek tersebut meningkat, maka pemahaman siswa terhadap materi pelajaran, kemampuan berpendapat, dan hasil belajar siswa akan meningkat juga, termasuk kemandirian belajar siswa pada indikator aktif dalam belajar juga mengalami peningkatan.

Kemampuan siswa pada indikator aktif dalam belajar ini akan membuat siswa lebih berpartisipasi dalam kegiatan belajarnya, sehingga siswa akan lebih mengalami peningkatan pengetahuan, pemahaman, keterampilan, dan pengalaman, di mana hal tersebut dapat membantu meningkatkan hasil belajar siswa. Hal serupa juga dijelaskan oleh Ningsih (2018) serta Ramlah, Firmansyah, dan Zubair (2014), bahwa hasil belajar siswa yang memiliki keaktifan tinggi dalam kegiatan 
belajarnya akan lebih tinggi dibandingkan dengan hasil belajar siswa dengan keaktifan rendah dalam kegiatan belajarnya.

\section{b. Indikator Tidak Ketergantungan kepada Orang Lain}

Hasil pengukuran tingkat kemandirian belajar siswa berdasarkan indikator tidak ketergantungan kepada orang lain menunjukkan, bahwa sebagian besar siswa memiliki tingkat kemandirian belajar yang termasuk ke dalam kategori tinggi hingga sangat tinggi. Tetapi, masih terdapat cukup banyak siswa yang memiliki tingkat kemandirian belajar dalam kategori rendah, yaitu sebanyak 16,36\% siswa. Hasil tersebut dapat dilihat pada Tabel 8.

Tabel 8. Tingkat Kemandirian Belajar Siswa Berdasarkan Indikator Tidak Ketergantungan kepada Orang Lain

\begin{tabular}{cccc}
\hline Interval Nilai & $\begin{array}{c}\text { Kategori Tingkat Kemandirian Jumlah Siswa Persentase (\%) } \\
\text { Belajar }\end{array}$ \\
\hline$X \geq 16$ & Sangat Tinggi & 21 & 38,18 \\
\hline $13 \leq X<16$ & Tinggi & 25 & 45,45 \\
\hline $10 \leq X<13$ & Rendah & 9 & 16,36 \\
\hline$X<10$ & Sangat Rendah & 0 & 0,00 \\
\hline \multicolumn{2}{c}{ Jumlah } & 55 & 100 \\
\hline
\end{tabular}

Keterangan: $\mathrm{X}=$ total nilai siswa pada indikator ini

Secara lebih spesifik dalam pengukuran tingkat kemandirian belajar siswa pada indikator ini diketahui juga, bahwa terdapat aspek dalam indikator ini yang kurang diterapkan oleh siswa, yaitu aspek dalam hal mempelajari materi pelajaran tanpa menunggu perintah dari guru, terbukti dari aspek tersebut yang memperoleh nilai terendah dalam pengukuran tingkat kemandirian belajar berdasarkan indikator ini. Nilai tersebut dapat dilihat pada Tabel 9.

Tabel 9. Penerapan Kemandirian Belajar oleh Siswa Berdasarkan Pernyataan pada Indikator Tidak Ketergantungan kepada Orang Lain

\begin{tabular}{|c|c|c|c|c|c|c|}
\hline \multirow{2}{*}{$\begin{array}{c}\text { Nomor } \\
\text { Pernyataan }\end{array}$} & \multirow{2}{*}{ Pernyataan } & \multicolumn{4}{|c|}{ Jumlah Siswa } & \multirow{2}{*}{$\begin{array}{l}\text { Total } \\
\text { Skor }\end{array}$} \\
\hline & & 1 & 2 & 3 & 4 & \\
\hline P5 & $\begin{array}{l}\text { Saya selalu mempelajari materi DPBHP yang } \\
\text { diberikan dalam kegiatan PJJ secara mandiri } \\
\text { tanpamenunggu perintah dari } \\
\text { guru. }\end{array}$ & 3 & 27 & 22 & 3 & 135 \\
\hline P6 & $\begin{array}{l}\text { Saya selalu mengerjakan kuis yang diberikan } \\
\text { dalam kegiatan PJJ mata } \\
\text { pelajaran DPBHP tanpameminta bantuan teman. }\end{array}$ & 0 & 10 & 32 & 13 & 168 \\
\hline P7 & $\begin{array}{l}\text { Saya selalu mengerjakantugas mata pelajaran } \\
\text { DPBHP yang diberikan } \\
\text { dalam kegiatan PJJ tanpabantuan orang tua. }\end{array}$ & 1 & 4 & 17 & 33 & 192 \\
\hline P8 & $\begin{array}{l}\text { Saya selalu mengerjakantugas mata pelajaran } \\
\text { DPBHP yang diberikan dalam kegiatan PJJ tanpa } \\
\text { bantuan teman }\end{array}$ & 4 & 12 & 27 & 12 & 157 \\
\hline P9 & $\begin{array}{l}\text { Saya tidak perlu diingatkan untuk mengerjakan } \\
\text { tugas yang diberikan dalam kegiatan PJJ mata } \\
\text { pelajaran DPBHP. }\end{array}$ & 2 & 16 & 28 & 9 & 154 \\
\hline
\end{tabular}

Keterangan: 1 = Sangat Tidak Sesuai, 2 = Tidak Sesuai, 3 = Sesuai, 4 = Sangat Sesuai

Informasi yang diperoleh dari hasil pengukuran tingkat kemandirian belajar siswa pada indikator ini menunjukkan juga, bahwa aspek yang kurang diterapkan oleh siswa tersebut dapat menjadi salah satu penyebab dari kurang optimalnya hasil belajar siswa. Hal itu dikarenakan apabila siswa telah mampu untuk mempelajari materi pelajaran tanpa menunggu perintah dari guru, maka pemahaman terhadap materi pelajaran telah dibutuhkan siswa dan hal itu akan membuat siswa lebih mudah untuk 
memahami materi pelajaran, sehingga dapat meningkatkan hasil belajar siswa. Dijelaskan oleh Cahyasari dan Dewi (2016), bahwa berinisiatif sendiri untuk belajar memiliki hubungan yang signifikan dengan hasil belajar siswa, di mana hasil belajar siswa akan semakin tinggi apabila semakin tinggi juga inisiatif siswa untuk belajar.

Berdasarkan hal tersebut, maka perlu upaya untuk meningkatkan kemampuan siswa dalam menerapkan aspek untuk berinisiatif mempelajari materi pelajaran tanpa menunggu perintah dari guru, yaitu dengan cara siswa perlu meningkatkan kemauan dan kebutuhannya untuk memahami materi pelajaran (Liando dan Lumettu, 2017). Hal itu akan membuat siswa terdorong untuk mempelajari materi dengan sendirinya dan akan membuat materi pelajaran lebih mudah dipahami. Ketika kemampuan siswa dalam menerapkan aspek tersebut meningkat, maka pemahaman siswa terhadap materi pelajaran dan hasil belajar siswa juga meningkat, termasuk kemandirian belajar siswa pada indikator tidak ketergantungan kepada orang lain juga mengalami peningkatan.

Kemampuan siswa dalam indikator tidak ketergantungan kepada orang lain ini akan membuat siswa hanya bergantung dan mengandalkan kemampuan dirinya sendiri dalam kegiatan belajar, sehingga ketika siswa menemui kegagalan dalam kegiatan belajar, siswa akan berusaha semaksimal mungkin untuk meningkatkan kemampuannya agar kegagalannya teratasi, di mana hal itu dapat membantu mengoptimalkan hasil belajar siswa. Hal itu dikarenakan belajar secara mandiri berkorelasi positif dengan hasil belajar siswa, sebab perilaku siswa yang mampu melaksanakan kegiatan belajar sendiri dan tidak bergantung kepada orang lain memberikan dampak yang baik terhadap hasil belajar siswa (Inah, Ghazali, dan Santoso, 2017).

\section{c. Indikator Mampu Mengontrol Diri}

Hasil pengukuran tingkat kemandirian belajar siswa berdasarkan indikator mampu mengontrol diri menunjukkan, bahwa sebagian besar siswa memiliki tingkat kemandirian belajar yang termasuk ke dalam kategori tinggi hingga sangat tinggi. Tetapi, masih terdapat cukup banyak siswa yang memiliki tingkat kemandirian belajar dalam kategori rendah hingga sangat rendah, yaitu masing-masing sebanyak 20,00\% siswa dan 5,45\% siswa. Hasil tersebut dapat dilihat pada Tabel 10.

Tabel 10. Tingkat Kemandirian Belajar Siswa Berdasarkan Indikator Mampu Mengontrol Diri

\begin{tabular}{cccc}
\hline Interval Nilai & $\begin{array}{c}\text { Kategori Tingkat } \\
\text { Kemandirian Belajar }\end{array}$ & $\begin{array}{c}\text { Jumlah } \\
\text { Siswa }\end{array}$ & $\begin{array}{c}\text { Persentase } \\
(\%)\end{array}$ \\
\hline$X \geq 16$ & Sangat Tinggi & 12 & 21,82 \\
\hline $13 \leq X<16$ & Tinggi & 29 & 52,73 \\
\hline $10 \leq X<13$ & Rendah & 11 & 20,00 \\
\hline$X<10$ & Sangat Rendah & 3 & 5,45 \\
\hline \multicolumn{2}{c}{ Jumlah } & 55 & 100 \\
\hline
\end{tabular}

Keterangan: $\mathrm{X}=$ total nilai siswa pada indikator ini

Secara lebih spesifik dalam pengukuran tingkat kemandirian belajar siswa pada indikator ini diketahui juga, bahwa terdapat aspek dalam indikator ini yang kurang diterapkan oleh siswa, yaitu aspek dalam hal memiliki fokus yang baik ketika mempelajari materi DPBHP dalam kegiatan PJJ, terbukti dari aspek tersebut yang memperoleh nilai terendah dalam pengukuran tingkat kemandirian belajar siswa berdasarkan indikator ini. Nilai aspek tersebut dapat dilihat pada Tabel 11 .

Informasi yang diperoleh dari hasil pengukuran tingkat kemandirian belajar siswa pada indikator ini menunjukkan juga, bahwa aspek yang kurang diterapkan oleh siswa tersebut dapat menjadi salah satu penyebab dari kurang optimalnya hasil belajar siswa. Hal itu dikarenakan apabila siswa melaksanakan kegiatan belajar dengan fokus yang baik, maka kegiatan belajar dapat berlangsung lebih baik, pemahaman terhadap materi pelajaran akan berlangsung lebih mudah, penyelesaian tugas belajar dapat berlangsung lebih baik, dan pengerjaan ujian dapat memperoleh hasil yang lebih baik, di mana hal itu akan membantu siswa memperoleh hasil belajar yang lebih baik lagi. Pujiyanto dan Sulistiyowati (2016) menjelaskan, bahwa fokus belajar memiliki hubungan yang signifikan dengan hasil belajar. 
Tabel 11. Penerapan Kemandirian Belajar oleh Siswa Berdasarkan Pernyataan pada Indikator Mampu Mengontrol Diri

\begin{tabular}{|c|l|l|l|l|l|c|}
\hline \multirow{2}{*}{$\begin{array}{c}\text { Nomor } \\
\text { Pernyataan }\end{array}$} & \multicolumn{1}{|c|}{ Pernyataan } & \multicolumn{3}{|c|}{ Jumlah Siswa } & \multirow{2}{*}{$\begin{array}{c}\text { Total } \\
\text { Skor }\end{array}$} \\
\cline { 2 - 6 } P10 & $\begin{array}{l}\text { Saya mampu menghilangkan } \\
\text { rasa malas untuk } \\
\text { melaksanakan PJJ pada } \\
\text { mata pelajaran DPBHP. }\end{array}$ & 2 & 7 & 39 & 7 & 161 \\
\hline P11 & $\begin{array}{l}\text { Saya mampu menentukan skala } \\
\text { prioritas selama PJJ pada mata } \\
\text { pelajaran DPBH, baik ketika } \\
\text { belajar, mengerjakan tugas, } \\
\text { atau } \\
\text { bermain ponsel. }\end{array}$ & 17 & 28 & 10 & 158 \\
\hline P12 & $\begin{array}{l}\text { Saya mampu menahan godaan } \\
\text { untuk tidak bermainponsel ketika } \\
\text { PJJ pada mata } \\
\text { pelajaran DPBHP. }\end{array}$ & 4 & 16 & 28 & 7 & 148 \\
\hline P13 & $\begin{array}{l}\text { Saya mampu berkonsentrasi } \\
\text { dengan baik dalam } \\
\text { mempelajari materi DPBHPpada } \\
\text { pelaksanaan PJJ. }\end{array}$ & 1 & 12 & 36 & 6 & 157 \\
\hline P14 & $\begin{array}{l}\text { Saya memiliki fokus yang baik } \\
\text { ketika mempelajari materi } \\
\text { DPBHP dalam } \\
\text { kegiatan PJJ. }\end{array}$ & 2 & 19 & 30 & 4 & 146 \\
\hline
\end{tabular}

Berdasarkan hal tersebut, maka perlu upaya untuk meningkatkan kemampuan siswa dalam menerapkan aspek untuk memiliki fokus yang baik ketika mempelajari materi DPBHP dalam kegiatan PJJ, yaitu dengan cara siswa perlu membagi waktu yang dimilikinya dengan baik, memisahkan waktu belajar dan waktu ketika tidak belajar, selain itu siswa juga dapat menciptakan suasana seperti belajar di sekolah dengan menjalankan aktivitas rutin yang biasa dilakukannya ketika akan pergi ke sekolah, seperti bangun pagi, sarapan, dan mengenakan pakaian sekolah (Yang, 2020). Ketika kemampuan siswa dalam menerapkan aspek tersebut meningkat, maka diharapkan hasil belajar siswa dan kemandirian belajar siswa pada indikator mampu mengontrol diri juga mengalami peningkatan.

Kemampuan siswa pada indikator mampu mengontrol diri ini akan membuat kegiatan belajar siswa menjadi lebih kondusif dan berlangsung ke arah yang positif, di mana ketika hal tersebut terjadi maka dapat meningkatkan kualitas belajar siswa dan hasil belajar siswa. Hal itu disebabkan, apabila siswa mampu untuk menyusun, membimbing, mengatur, dan mengarahkan perilakunya ke arah yang positif dalam kegiatan belajar, maka kontrol belajar siswa dalam kegiatan belajar sudah baik dan dengan hal itu kegiatan belajar siswa akan lebih berhasil dan hasil belajar siswa akan lebih optimal (Sari, Yusri, dan Said, 2017).

\section{d. Berdasarkan Indikator Percaya Diri dalam Belajar}

Hasil pengukuran tingkat kemandirian belajar siswa berdasarkan indikator percaya diri dalam belajar menunjukkan bahwa sebagian besar siswa memiliki tingkat kemandirian belajar yang termasuk ke dalam kategori tinggi hingga sangat tinggi. Tetapi, masih terdapat cukup banyak siswa yang memiliki tingkat kemandirian belajar dalam kategori rendah hingga sangat rendah, yaitu masing-masing sebanyak 16,36\% siswa dan 1,82\% siswa. Hasil tersebut dapat dilihat pada Tabel 12. 
Tabel 12. Tingkat Kemandirian Belajar Siswa Berdasarkan Indikator Percaya Diri dalam Belajar

\begin{tabular}{|c|c|c|c|}
\hline Interval Nilai & $\begin{array}{c}\text { Kategori Tingkat } \\
\text { Kemandirian Belajar }\end{array}$ & $\begin{array}{c}\text { Jumlah } \\
\text { Siswa }\end{array}$ & $\begin{array}{c}\text { Persentase } \\
(\%)\end{array}$ \\
\hline$X \geq 16$ & Sangat Tinggi & 17 & 30,91 \\
\hline $13 \leq X<16$ & Tinggi & 28 & 50,91 \\
\hline $10 \leq x<13$ & Rendah & 9 & 16,36 \\
\hline$x<10$ & Sangat Rendah & 1 & 1.82 \\
\hline \multicolumn{2}{|r|}{ Jumlah } & 55 & 100 \\
\hline
\end{tabular}

Keterangan: $\mathrm{X}=$ total nilai siswa pada indikator ini

Secara lebih spesifik dalam pengukuran tingkat kemandirian belajar siswa pada indikator ini diketahui juga, bahwa terdapat aspek dalam indikator ini yang kurang diterapkan oleh siswa, yaitu aspek dalam hal selalu percaya diri untuk berpendapat ketika pembelajaran berlangsung, terbukti dari aspek tersebut yang memperoleh nilai terendah dalam pengukuran tingkat kemandirian belajar berdasarkan indikator ini. Nilai tersebut dapat dilihat pada Tabel 13.

Tabel 13. Penerapan Kemandirian Belajar oleh Siswa Berdasarkan Pernyataan pada Indikator Percaya Diri dalam Belajar

\begin{tabular}{|c|c|c|c|c|c|c|}
\hline \multirow{2}{*}{$\begin{array}{c}\text { Nomor } \\
\text { Pernyataan }\end{array}$} & \multirow{2}{*}{ Pernyataan } & \multicolumn{4}{|c|}{ Jumlah Siswa } & \multirow{2}{*}{$\begin{array}{l}\text { Total } \\
\text { Skor }\end{array}$} \\
\hline & & 1 & 2 & 3 & 4 & \\
\hline P15 & $\begin{array}{l}\text { Saya selalu percaya diri untuk menyampaikan } \\
\text { pendapat saya ketika pelaksanaan PJJ mata } \\
\text { pelajaran DPBHP. }\end{array}$ & 6 & 25 & 20 & 4 & 132 \\
\hline P16 & $\begin{array}{l}\text { Saya selalu percaya dirimampu mengerjakantugas } \\
\text { mata pelajaran DPBHP yang diberikandalam kegiatan } \\
\text { PJJ tanpa bantuan orang lain. }\end{array}$ & 1 & 11 & 29 & 14 & 166 \\
\hline P17 & $\begin{array}{l}\text { Saya selalu percaya diridengan hasil tugas yang saya } \\
\text { kerjakan sendiri } \\
\text { pada kegiatan PJJ matapelajaran DPBHP. }\end{array}$ & 0 & 6 & 32 & 17 & 176 \\
\hline P18 & $\begin{array}{l}\text { Saya selalu percaya dirisaya mampu } \\
\text { mengerjakan kuis mata pelajaran DPBHP dalam } \\
\text { kegiatan PJJ tanpa bantuan orang lain. }\end{array}$ & 1 & 9 & 33 & 12 & 166 \\
\hline P19 & $\begin{array}{l}\text { Saya yakin bahwa gayabelajar yang saya gunakan } \\
\text { dalam PJJ pada mata pelajaran DPBHP } \\
\text { sudah baik. }\end{array}$ & 1 & 13 & 34 & 7 & 157 \\
\hline
\end{tabular}

Keterangan: 1 = Sangat Tidak Sesuai, 2 = Tidak Sesuai, 3 = Sesuai, 4 = Sangat Sesuai

Informasi yang diperoleh dari hasil pengukuran tingkat kemandirian belajar siswa pada indikator ini menunjukkan juga, bahwa aspek yang kurang diterapkan oleh siswa tersebut dapat menjadi salah satu penyebab dari kurang optimalnya hasil belajar siswa. Hal itu dikarenakan apabila siswa telah percaya diri untuk berpendapat, maka siswa telah mengalami peningkatan pengetahuan dan pemahaman terhadap materi pelajaran dengan baik, sehingga hal itu akan lebih memperkaya pemikirannya dan akan meningkatkan kepercayaan diri serta kemampuan siswa untuk berpendapat, di mana hal itu akan meningkatkan hasil belajar siswa. Sikap siswa yang percaya diri untuk mengemukakan pendapat akan berpengaruh positif terhadap hasil belajar siswa, sebab ketika rasa percaya diri siswa untuk berpendapat semakin tinggi, maka hasil belajar siswa akan semakin tinggi juga (Rifki, 2008).

Berdasarkan hal tersebut, maka perlu upaya untuk meningkatkan kemampuan siswa dalam menerapkan aspek untuk selalu percaya diri dalam berpendapat ketika pembelajaran berlangsung, yaitu dengan cara meningkatkan pemahaman dan pengetahuannya terhadap materi pelajaran, sehingga rasa ragu untuk berpendapat akan hilang dan rasa percaya diri untuk berpendapat akan muncul. Ketika kemampuan siswa dalam menerapkan aspek tersebut meningkat, maka diharapkan pemahaman siswa terhadap materi pelajaran, rasa percaya diri untuk berpendapat, dan hasil belajar 
siswa akan meningkat, termasuk kemandirian belajar siswa pada indikator percaya diri dalam belajar juga mengalami peningkatan.

Kemampuan siswa pada indikator percaya diri dalam belajar ini akan membuat siswa melaksanakan kegiatan belajar dengan penuh keyakinan dan tidak akan melakukan sesuatu hal dalam kegiatan belajar yang merugikannya hanya karena kurang percaya diri, sehingga kualitas pembelajaran dan hasil belajar siswa akan meningkat. Selain itu, ketika siswa yakin bahwa akan berhasil dalam kegiatan belajar, maka akan membuat siswa berusaha lebih keras dalam kegiatan belajarnya untuk membuktikan bahwa dirinya dapat berhasil dalam kegiatan belajar dengan mengoptimalkan kemampuannya. Hal itu dikarenakan, ketika dalam kegiatan belajar siswa memilki rasa percaya diri yang tinggi, maka hasil belajar yang diperoleh siswa akan tinggi juga, sebab rasa percaya memiliki hubungan yang signifikan dengan hasil belajar (Warman, 2013).

\section{e. Indikator Disiplin dalam Belajar}

Hasil pengukuran tingkat kemandirian belajar siswa berdasarkan indikator disiplin dalam belajar menunjukkan bahwa sebagian besar siswa memiliki tingkat kemandirian belajar yang termasuk dalam kategori tinggi hingga sangat tinggi. Tetapi, masih terdapat cukup banyak siswa yang memiliki tingkat kemandirian belajar dalam kategori rendah hingga sangat rendah, yaitu masing-masing sebanyak 23,64\% siswa dan 1,82\% siswa. Hasil tersebut dapat dilihat pada Tabel 14.

Tabel 14. Tingkat Kemandirian Belajar Siswa Berdasarkan Indikator Disiplin dalam Belajar

\begin{tabular}{|c|c|c|c|}
\hline Interval Nilai & $\begin{array}{c}\text { Kategori Tingkat } \\
\text { Kemandirian Belajar }\end{array}$ & $\begin{array}{c}\text { Jumlah } \\
\text { Siswa }\end{array}$ & $\begin{array}{c}\text { Persentase } \\
(\%)\end{array}$ \\
\hline$x \geq 12$ & $\begin{array}{l}\text { Sangat Tinggi } \\
\end{array}$ & 35 & 63,64 \\
\hline $10 \leq X<12$ & Tinggi & 6 & 10,91 \\
\hline $8 \leq X<10$ & Rendah & 13 & 23,64 \\
\hline$X<8$ & Sangat Rendah & 1 & 1,82 \\
\hline \multicolumn{2}{|r|}{ Jumlah } & 55 & 100 \\
\hline
\end{tabular}

Keterangan: $\mathrm{X}=$ total nilai siswa pada indikator ini

Secara lebih spesifik hasil pengukuran tingkat kemandirian belajar siswa pada indikator ini diketahui juga, bahwa terdapat aspek dalam indikator ini yang kurang diterapkan oleh siswa, yaitu aspek dalam hal tepat waktu mengerjakan tugas belajar, mengerjakan kuis, dan mengisi absensi di Google Classroom, terbukti dari aspek-aspek tersebut yang memperoleh nilai terendah dalam pengukuran tingkat kemandirian belajar berdasarkan indikator ini. Nilai tersebut dapat dilihat pada Tabel 15.

Tabel 15. Penerapan Kemandirian Belajar oleh Siswa Berdasarkan Pernyataan pada Indikator Disiplin dalam Belajar

\begin{tabular}{|c|c|c|c|c|c|c|}
\hline \multirow{2}{*}{$\begin{array}{c}\text { Nomor } \\
\text { Pernyataan }\end{array}$} & \multirow{2}{*}{ Pernyataan } & \multicolumn{4}{|c|}{ Jumlah Siswa } & \multirow[t]{2}{*}{ TotalSkor } \\
\hline & & 1 & 2 & 3 & 4 & \\
\hline P20 & $\begin{array}{l}\text { Saya selalu mengerjakan tugas yang } \\
\text { diberikan oleh guru dalam kegiatan PJJ mata } \\
\text { pelajaran DPBHP } \\
\text { tepat waktu. }\end{array}$ & 0 & 15 & 27 & 13 & 163 \\
\hline P21 & $\begin{array}{l}\text { Saya selalu mengerjakan kuis yang diberikan } \\
\text { dalam kegiatan PJJ mata pelajaran DPBHP } \\
\text { dengan tepat waktu. }\end{array}$ & 0 & 16 & 25 & 14 & 163 \\
\hline $\mathrm{P} 22$ & $\begin{array}{l}\text { Saya selalu tepat waktu dalam mengikuti } \\
\text { kegiatan PJJ mata pelajaran DPBHP yang } \\
\text { dilakukan melalui aplikasi Zoom. }\end{array}$ & 2 & 10 & 23 & 20 & 171 \\
\hline P23 & $\begin{array}{l}\text { Saya selalu tepat waktu dalam mengisi } \\
\text { absensi di Google Classroom untukkegiatan } \\
\text { PJJ mata pelajaran DPBHP. }\end{array}$ & 0 & 17 & 23 & 15 & 163 \\
\hline
\end{tabular}

Keterangan: 1 = Sangat Tidak Sesuai, 2 = Tidak Sesuai, 3 = Sesuai, 4 = Sangat Sesuai 
Informasi yang diperoleh dari hasil pengukuran tingkat kemandirian belajar siswa pada indikator ini menunjukkan juga, bahwa aspek yang kurang diterapkan oleh siswa tersebut dapat menjadi salah satu penyebab dari kurang optimalnya hasil belajar siswa. Hal itu dikarenakan apabila siswa mampu mengerjakan tugas belajar dengan tepat waktu, maka waktu belajar siswa telah teratur dengan baik yang membuat seluruh tugas belajar terselesaikan dengan baik, sehingga akan memperoleh nilai tugas belajar yang baik pula. Suryadi, Erlamsyah, dan Yusri (2017) menjelaskan, bahwa hasil belajar yang baik dapat diperoleh siswa apabila kemampuan siswa dalam mengerjakan tugas semakin baik.

Berdasarkan hal tersebut, perlu upaya untuk meningkatkan kemampuan siswa dalam menerapkan aspek untuk mengerjakan tugas belajar dengan tepat waktu, yaitu dengan cara mengelompokkan waktu belajar untuk kegiatan belajar dan mengerjakan tugas belajar (Suryadi, Erlamsyah, dan Yusri). Ketika kemampuan siswa dalam menerapkan aspek tersebut meningkat, maka diharapkan tugas belajar siswa dapat terselesaikan dengan baik dan hasil belajar siswa juga meningkat, termasuk kemandirian belajar siswa pada indikator disiplin dalam belajar juga mengalami peningkatan

Kemampuan siswa pada indikator disiplin dalam belajar ini akan membuat kegiatan belajar siswa menjadi lebih teratur, tertib, dan taat terhadap peraturan yang berlaku dalam kegiatan belajar, di mana hal itu akan membuat kegiatan belajar siswa menjadi jauh lebih berkualitas, sehingga dapat meningkatkan hasil belajar siswa. Disiplin tinggi dalam kegiatan belajar yang diterapkan oleh siswa akan berdampak positif terhadap hasil belajar siswa, sebab apabila siswa memiliki kedisiplinan yang semakin tinggi dalam kegiatan belajar, maka hasil belajar siswa akan semakin tinggi juga (Afridiani, 2017).

\section{f. Indikator Bertanggung Jawab dalam Belajar}

Hasil pengukuran tingkat kemandirian belajar siswa berdasarkan indikator bertanggung jawab dalam belajar menunjukkan bahwa seluruh siswa memiliki tingkat kemandirian belajar yang termasuk ke dalam kategori tinggi hingga sangat tinggi. Hasil tersebut dapat dilihat pada Tabel 16.

Tabel 16. Tingkat Kemandirian Belajar Siswa Berdasarkan Indikator Bertanggung Jawab dalam

$$
\text { Belajar }
$$

\begin{tabular}{cccc}
\hline Interval Nilai & $\begin{array}{c}\text { Kategori Tingkat } \\
\text { Kemandirian Belajar }\end{array}$ & $\begin{array}{c}\text { Jumlah } \\
\text { Siswa }\end{array}$ & $\begin{array}{c}\text { Persentase } \\
(\%)\end{array}$ \\
\hline $\mathrm{X} \geq 12$ & Sangat Tinggi & 40 & 72,73 \\
\hline $10 \leq \mathrm{X}<12$ & Tinggi & 15 & 27,27 \\
\hline $8 \leq \mathrm{X}<10$ & Rendah & 0 & 0,00 \\
\hline $\mathrm{X}<8$ & Sangat Rendah & 0 & 0,00 \\
\hline Jumlah & 55 & 100 & \\
\hline
\end{tabular}

Keterangan: $\mathrm{X}=$ total nilai siswa pada indikator ini

Secara lebih spesifik dalam pengukuran tingkat kemandirian belajar siswa pada indikator ini diketahui juga, bahwa terdapat aspek dalam indikator ini yang kurang diterapkan oleh siswa, yaitu aspek dalam hal selalu mempelajari seluruh materi pelajaran DPBHP yang diberikan dalam kegiatan PJJ, terbukti dari aspek tersebut yang memperoleh nilai terendah dalam pengukuran tingkat kemandirian belajar berdasarkan indikator ini. Nilai tersebut dapat dilihat pada Tabel 17.

Informasi yang diperoleh dari hasil pengukuran tingkat kemandirian belajar siswa pada indikator ini menunjukkan juga, bahwa aspek yang kurang diterapkan oleh siswa tersebut dapat menjadi salah satu penyebab dari kurang optimalnya hasil belajar siswa. Hal itu dikarenakan apabila siswa mau untuk mempelajari seluruh materi pelajaran yang diberikan, maka pemahaman siswa terhadap materi pelajaran akan menyeluruh. Pemahaman terhadap materi yang menyeluruh dapat meningkatkan hasil belajar siswa, sebab dijelaskan oleh Sappaile (2019), bahwa pemahaman siswa terhadap materi pelajaran berkorelasi positif dengan hasil belajar. 
Tabel 17. Penerapan Kemandirian Belajar oleh Siswa Berdasarkan Pernyataan pada Indikator Bertanggung Jawab dalam Belajar

\begin{tabular}{|c|c|c|c|c|c|c|}
\hline \multirow{2}{*}{$\begin{array}{c}\text { Nomor } \\
\text { Pernyataan }\end{array}$} & \multirow{2}{*}{ Pernyataan } & \multicolumn{4}{|c|}{ Jumlah Siswa } & \multirow{2}{*}{$\begin{array}{l}\text { Total } \\
\text { Skor }\end{array}$} \\
\hline & & 1 & 2 & 3 & 4 & \\
\hline P24 & $\begin{array}{l}\text { Saya selalu mengerjakan } \\
\text { seluruh tugas yang diberikan } \\
\text { pada PJJ mata } \\
\text { pelajaran DPBHP. }\end{array}$ & 0 & 12 & 20 & 23 & 176 \\
\hline P25 & $\begin{array}{l}\text { Saya selalu mempelajari } \\
\text { seluruh materi DPBHP yang } \\
\text { diberikan pada } \\
\text { kegiatan PJJ. }\end{array}$ & 0 & 12 & 40 & 3 & 156 \\
\hline P26 & $\begin{array}{l}\text { Saya selalu berusaha } \\
\text { memperoleh hasil belajar } \\
\text { yang baik pada PJJ mata } \\
\text { pelajaran DPBHP. }\end{array}$ & 0 & 3 & 30 & 22 & 184 \\
\hline P27 & $\begin{array}{l}\text { Saya selalui mengikuti } \\
\text { kegiatan PJJ matapelajaran } \\
\text { DPBHP yang } \\
\text { dilakukan melalui Google } \\
\text { Classroom. }\end{array}$ & 0 & 3 & 26 & 26 & 188 \\
\hline
\end{tabular}

Berdasarkan hal tersebut, maka perlu upaya untuk meningkatkan kemampuan siswa dalam menerapkan aspek untuk mempelajari seluruh materi yang diberikan dalam kegiatan pembelajaran, yaitu dengan cara meningkatkan minat siswa untuk belajar, sehingga siswa akan dengan sendirinya mempelajari materi pelajaran dan akan merasa senang ketika mempelajarinya. Ketika kemampuan siswa dalam menerapkan aspek tersebut meningkat, maka pemahaman siswa terhadap materi pelajaran dan hasil belajar siswa akan meningkat, termasuk kemandirian belajar siswa pada indikator bertanggung jawab dalam belajar juga mengalami peningkatan.

Kemampuan siswa pada indikator bertanggung jawab dalam belajar akan membuat kegiatan belajar siswa berlangsung lebih baik, sebab ketika kegiatan belajar dilaksanakan dengan penuh tanggung jawab maka dapat berlangsung dengan baik dan memperoleh hasil belajar yang baik juga. Sugeng (2020) dan Syafitri (2017) menjelaskan, bahwa tanggung jawab siswa yang baik dalam kegiatan belajarnya akan membantu siswa memperoleh hasil belajar yang optimal, sebab tanggung jawab dalam belajar memiliki hubungan yang positif dengan hasil belajar.

\section{KESIMPULAN}

Hasil pengukuran tingkat kemandirian belajar siswa kelas X APHP di SMK PPN Lembang dalam PJJ mata pelajaran DPBHP pada tahun ajaran 2020/2021 berdasarkan indikator kemandirian belajar yang dilihat dari sudut pandang sikap siswa ketika belajar menunjukkan, bahwa seluruh siswa memiliki kemandirian belajar dalam kategori Tinggi hingga Sangat Tinggi pada indikator bertanggung jawab dalam belajar, sementara pada kelima indikator lainnya, yaitu indikator aktif dalam belajar, indikator tidak ketergantungan kepada orang lain, indikator mampu mengontrol diri, indikator percaya diri dalam belajar, dan indikator disiplin dalam belajar hasil pengukuran menunjukkan, bahwa sebagian besar siswa memiliki tingkat kemandirian belajar dalam kategori Tinggi hingga Sangat Tinggi pada masing-masing indikator tersebut.

Meskipun hasil pengukuran kemandirian belajar siswa telah menunjukkan hasil yang baik, tetapi terdapat beberapa aspek dalam indikator kemandirian belajar yang kurang diterapkan siswa dalam kegiatan belajarnya, yaitu berpendapat ketika pembelajaran, mempelajari materi pelajaran secara mandiri, memiliki fokus yang baik ketika belajar, percaya diri untuk berpendapat, mengerjakan tugas tepat waktu, dan mempelajari materi pelajaran secara keseluruhan. Aspek-aspek tersebut perlu menjadi perhatian, baik oleh guru, siswa, dan juga orang tua, di mana apabila penerapan aspek- aspek 
tersebut ditingkatkan oleh siswa maka diharapkan dapat meningkatkan kemandirian belajar siswa dan hasil belajar siswa. Selain itu dengan hasil pengukuran tingkat kemandirian belajar siswa ini menunjukkan juga, bahwa kemandirian belajar siswa bukan merupakan faktor utama penyebab hasil belajar siswa kelas X APHP di SMK PPN Lembang dalam PJJ mata pelajaran DPBHP kurang optimal, sebab hasil belajar siswa juga dipengaruhi oleh faktor eksternal siswa.

\section{DAFTAR PUSTAKA}

Afridiani, W. (2017). Hubungan Percaya Diri dan Disiplin Belajar dengan Hasil Belajar Mengolah Makanan Kontinental di SMK Negeri 1 Kisaran. Skripsi Jurusan Pendidikan Kesejahteraan Keluarga. (Skripsi). Program Studi Pendidikan Tata Boga, Fakultas Teknik, Universitas Negeri Medan, Medan.

Andriessen, J. \& Baker, M. J. (2014). Arguing to Learn. [Online]. Diakses dari https://www.researchgate.net/publication/316327995_Arguing_to_learn

Arif, L., \& Samidjo, S. (2018). Hubungan antara Sikap Belajar dan Motivasi Belajar Kejuruan dengan Hasil Belajar Gambar Teknik. Jurnal Taman Vokasi, 6(1), 92-97.

Azwar, S. (2017). Penyusunan Skala Psikologi. Yogyakarta: Pustaka Pelajar.

Cahyasari, I \& Dewi, R. M. (2016). Kebiasaan Belajar dan Kemandirian Belajar Terhadap Hasil Belajar Siswa. Jurnal Pendidikan Ekonomi (JUPE), 4(3), 1-7. doi: https://doi.org/10.26740/jupe.v4n3.p\%25p

Djemari, M. (2008). Teknik Penyusunan Instrumen Tes dan Nontes. Yogyakarta: Mitra Cendikia.

Febriastuti, Y. D. (2013). Peningkatan Kemandirian Belajar Siswa SMP Negeri 2 Geyer Melalui Pembelajaran Inkuiri Berbasis Proyek. (Skripsi). Program Studi Pendidikan Fisika, Fakultas Matematika dan IImu Alam, Universitas Negeri Semarang, Semarang.

Handayani, N. \& Hidayat, F. (2018). Hubungan Kemandirian Terhadap Hasil Belajar Siswa Mata Pelajaran Matematika di Kelas X SMK Kota Cimahi. Journal on Education, 1(2), 1-8. doi: https://doi.org/10.31004/joe.v1i2.16

Hendryadi, H. (2017). Validitas Isi: Tahap Awal Pengembangan Kuesioner. Jurnal Riset Manajemen dan Bisnis (JRMB) Fakultas Ekonomi UNIAT, 2(2), 169-178. doi: https://doi.org/10.36226/jrmb.v2i2.47

Hidayati, K. \& Listyani, E. (2010). Improving Instruments of Students Self-Regulated Learning. [Online]. Diaksesdari

http://staffnew.uny.ac.id/upload/132296141/penelitian/Pengembangan+Instrumen.p df

Inah, E. N., Ghazali, M., \& Santoso, E. (2017). Hubungan Belajar Mandiri dengan Prestasi Belajar PAI di MtsN 1 Konawe Selatan. Al-TA'DIB: Jurnal Kajian IImu Kependidikan, 10(2), 19-36. doi: http://dx.doi.org/10.31332/atdb.v10i2.622

Kementerian Pendidikan dan Kebudayaan (2020). Surat Edaran Nomor 04 Tahun 2020 tentang Pelaksanaan Kebijakan Pendidikan dalam Masa Darurat Penyebaran Coronavirus Disease (Covid-19). Jakarta: Kemendikbud.

Liando, N. V., \& Lumettu, R. (2017). Students' Personal Initiative towards Their Speaking Performance. International Education Studies, 10(8), 21-28. doi: https://doi.org/10.5539/ies.v10n8p21

Moore, M. G. \& Kearsley, G. (2011). Distance education: A Systems View of Online Learning. Massachusetts: Cengage Learning.

Mudjiman, H. (2006). Belajar Mandiri. Yogyakarta: Pustaka Belajar.

Mustajab, M., Sriyono, S., \& Fatmaryanti, S. D. (2012). Penerapan Metode Pembelajaran Cooperative Script untuk Meningkatkan Partisipasi Belajar Siswa Kelas VIII A SMP Negeri 2 Karanggayam Tahun Pelajaran 2012/2013. Radiasi: Jurnal Berkala Pendidikan Fisika, 1(1), 37-40.

Ningsih, A. (2018). Pengaruh Keaktifan Siswa Terhadap Hasil Belajar Ekonomi Kelas X di SMAN 2 Gunung Sahilan. PEKA, 6(2), 157-163.

Polit, D. F. \& Beck, C. T. (2006). The Content Validity Index: Are You Sure You Know What's Being Reported? Critique and Recommendations. Research in Nursing \& Health, 29(5), 489-497. doi: https://doi.org/10.1002/nur.20147

Pujiyanto, H., \& Sulistiyowati, W. (2016). Analisa Pengaruh Fokus Belajar, Aktivitas Belajar dan Intelektual Bagi Mahasiswa Aktif terhadap Prestasi Belajar dengan Menggunakan Metode SEM. Jurnal Humaniora, 13(2), 62-66. 
Ramlah, R., Firmansyah, D., \& Zubair, H. (2014). Pengaruh Gaya Belajar dan Keaktifan Siswa Terhadap Prestasi Belajar Matematika (Survey Pada SMP Negeri di Kecamatan Klari Kabupaten Karawang). Jurnal IImiah Solusi, 1(3), 68-75.

Rifki, M. (2008). Pengaruh Rasa Percaya Diri Terhadap Prestasi Belajar Siswa di SMA Islam Almaarif Singosari Malang. (Skripsi). Jurusan Pendikan IPS, Fakultas Tarbiyah, UIN Malang, Malang.

Rohmat, A. (2014). Analisis Kemandirian Belajar Siswa Terhadap Hasil Belajar Rangkaian Listrik Di SMK Negeri 1 Cimahi. (Skripsi). Pendidikan Teknik Elektro, Fakultas Pendidikan Teknologi dan Kejuruan, Universitas Pendidikan Indonesia, Bandung.

Sappaile, N. (2019). Hubungan Pemahaman Konsep Perbandingan dengan Hasil Belajar Kimia Materi Stoikiometri. Jurnal IImu Pendidikan (JIP) STKIP Kusuma Negara, 10(2), 58-71.

Sari, S., Yusri, Y., \& Said, A. (2017). Kontrol Diri Siswa dalam Belajar dan Persepsi Siswa terhadap Upaya Guru BK untuk Meningkatkan Kontrol Diri. JPGI (Jurnal Penelitian Guru Indonesia), 2(1), 32-37. doi: https://doi.org/10.29210/02234jpgi0005

SMK PPN Lembang. (2021). Program Studi. [Online]. Di akses dari https://smkppnlembang.sch.id/program-studi.

Sugeng, S. (2020). Hubungan Antara Self Efficacy, Disiplin, Tanggung Jawab, dan Minat Belajar dengan Hasil Belajar Matematika. Jurnal Pendidikan dan Pembelajaran Khatulistiwa, 9(1), 1-13.

Supianti, I. (2016). Dampak Penerapan E-Learning dalam Pembelajaran Matematika Terhadap Kemandirian Belajar Mahasiswa. Teorema: Jurnal Teori dan Riset Matematika, 1(1), 1-6.

Suryadi, S., Erlamsyah, E., \& Yusri, Y. (2017). Hubungan Kemampuan Menyelesaikan Tugas-tugas Pelajaran dengan Hasil Belajar Siswa. Jurnal EDUCATIO: Jurnal Pendidikan Indonesia, 2(2), 1418. doi: https://doi.org/10.29210/12016260

Syafitri. (2017). Meningkatkan Tanggung Jawab Belajar Melalui Strategi Giving Questions and Getting Answers pada Siswa. Jurnal Penelitian dan Pengembangan Pendidikan. 1(2), 57-63. doi: http://dx.doi.org/10.23887/jppp.v1i2.12623

Tim BSE. (2013). Penanganan Bahan Hasil Pertanian dan Perikanan. Jakarta: Buku Sekolah Elektronik.

Warman, D. (2013). Hubungan Percaya Diri Siswa dengan Hasil Belajar Geografi Kelas XI IPS di SMA $N 1$ Bayang Kabupaten Pesisir Selatan. [Online]. Diakses dari http://ejournal.unp.ac.id/students/index.php/pgeo/article/view/576

Yang, F. (2020). 7 Ways to Stay Focused When Studying from Home During Coronavirus. [Online]. 